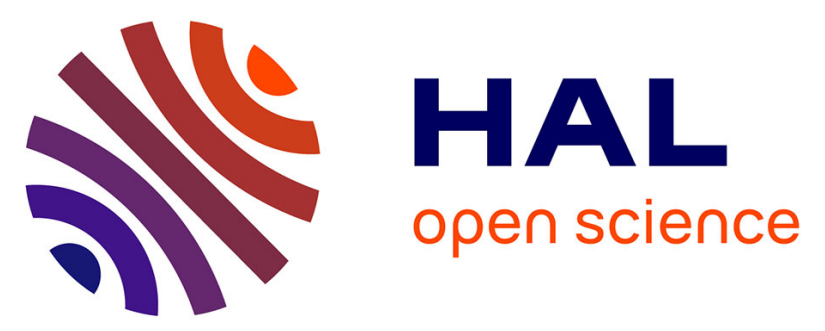

\title{
Design of 3D microbial anodes for microbial electrolysis cells (MEC) fuelled by domestic wastewater. Part I: Multiphysics modelling
}

Rémy Lacroix, Emma Roubaud, Benjamin Erable, Luc Etcheverry, Alain Bergel, Régine Basséguy, Serge da Silva

\section{To cite this version:}

Rémy Lacroix, Emma Roubaud, Benjamin Erable, Luc Etcheverry, Alain Bergel, et al.. Design of 3D microbial anodes for microbial electrolysis cells (MEC) fuelled by domestic wastewater. Part I: Multiphysics modelling. Journal of Environmental Chemical Engineering, 2021, 9 (4), pp.105476. 10.1016/j.jece.2021.105476 . hal-03253390

\section{HAL Id: hal-03253390 https://hal.science/hal-03253390}

Submitted on 8 Jun 2021

HAL is a multi-disciplinary open access archive for the deposit and dissemination of scientific research documents, whether they are published or not. The documents may come from teaching and research institutions in France or abroad, or from public or private research centers.
L'archive ouverte pluridisciplinaire HAL, est destinée au dépôt et à la diffusion de documents scientifiques de niveau recherche, publiés ou non, émanant des établissements d'enseignement et de recherche français ou étrangers, des laboratoires publics ou privés. 


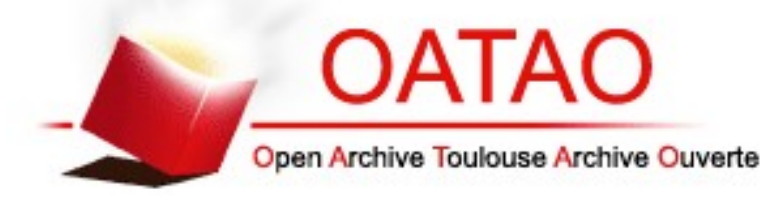

Open Archive Toulouse Archive Ouverte

OATAO is an open access repository that collects the work of Toulouse researchers and makes it freely available over the web where possible

This is an author's version published in: https://oatao.univ-toulouse.fr/27925

Official URL :

https://doi.org/10.1016/i.jece.2021.105476

\begin{tabular}{|c|}
\hline To cite this version: \\
\hline 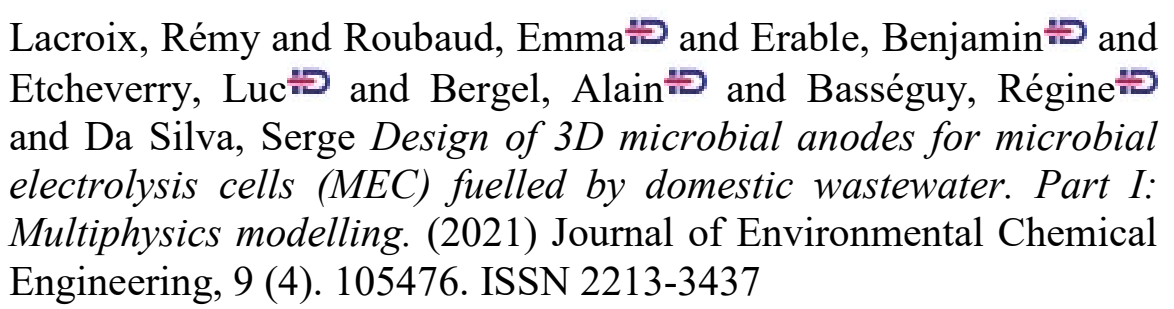 \\
\hline
\end{tabular}

Any correspondence concerning this service should be sent to the repository administrator: tech-oatao@listes-diff.inp-toulouse.fr 


\title{
Design of 3D microbial anodes for microbial electrolysis cells (MEC) fuelled by domestic wastewater. Part I: Multiphysics modelling
}

\author{
Rémy Lacroix $^{\mathrm{a}, *}$, Emma Roubaud ${ }^{\mathrm{b}}$, Benjamin Erable ${ }^{\mathrm{b}}$, Luc Etcheverry $^{\mathrm{b}}$, Alain Bergel ${ }^{\mathrm{b}}$, \\ Régine Basséguy ${ }^{\mathrm{b}}$, Serge Da Silva ${ }^{\mathrm{a}}$ \\ a 6T-MIC Ingénieries, 9 rue du développement, ZI de Vic les Graves, 31320 Castanet-Tolosan, France \\ ${ }^{\mathrm{b}}$ Laboratoire de Génie Chimique, Université de Toulouse, CNRS, INPT, UPS, Toulouse, France
}

\section{A R T I C L E I N F O}

\section{Keywords:}

Microbial electrolysis cell

Multiphysics modelling

Domestic wastewater treatment

Hydrogen production

3D graphite electrodes

Bioelectrochemical systems

\begin{abstract}
A B S T R A C T
The performance of a microbial electrolysis cell (MEC) supplied with domestic wastewater (dWW) is essentially limited by the kinetics of the anodic bioelectrochemical reactions and the low ionic conductivity of the electrolyte. A strategy to boost-up the anodic bioelectrochemical kinetics is to use three-dimensional (3D) microbial anodes that offer a high total anodic surface area and volume density of electroactive biofilm. In this work, a 3D multiphysics model was designed to simulate the current generation and resulting hydrogen production in double and triple-compartment MECs fed continuously with dWW. Simulations indicated that optimised 3D microbial anode geometries could simultaneously increase current and chemical oxygen demand (COD) removal by $86 \%$ compared to a $2 \mathrm{D}$ planar graphite electrode. At a constant CEM voltage, the current produced increased with the thickness of the 3D microbial anode up to a limiting thickness of $20 \mathrm{~mm}$. Beyond this value, the current was stagnant due to the predominant ohmic drop. Current generation and COD removal could be further increased by designing 3D anode geometrical arrangements that force the dWWs to flow through the porosity of the 3D microbial anode. A gain of $20 \%$ was calculated by substituting a monolithic 3D graphite anode with a 3D anode of the same thickness $(20 \mathrm{~mm})$ but constructed of plates stacked on top of each other and spaced $2.5 \mathrm{~mm}$ apart. Finally, hydrogen production performance was additionally optimised by a further $+20 \%$ by switching from a two-compartment MEC design (anode-cathode) to a three-compartment MEC design (cathode-anodecathode).
\end{abstract}

\section{Introduction}

Biological, chemical, and physical phenomena occurring in a microbial electrolysis cell (MEC) are complex: growth and development of microbial biofilms, abiotic and biotic reactions mass transfer, rheology (fluid flow), heat transfer as well as other multiphasic phenomena such as gas bubbling, biofouling or precipitation. Performance of MECs can be limited by one or several of these mentioned factors but, in a majority of cases, the oxidation kinetic of electroactive biofilm is slow and strongly limits the current in the cell and thus the hydrogen production rate at the cathode [1]. Several strategies can be applied to overcome these limitations, i.e. to significantly increase the oxidation current delivered by electroactive (EA) biofilms. One way consists in increasing the contact area between anodic material and the liquid phase. Several materials and geometries are used as bioanodes such as plates [2], rods [3], brush [4], felt [5], granules [6], 3D printed structures [7] electrodes manufactured by selective laser melting [8], cloth [9], foam [10] or composite electrodes [11]. Several review articles compare performances obtained in bioelectrochemical systems with these electrodes [12].

Modelling of MECs can be a powerful tool to design a priori (i) the configuration of reactor and compartment sizes, (ii) electrode size, geometry, porosity and electrical conductivity, (iii) the suitability and position of ionic membranes or gas separators, (iv) as well as the impact of experimental conditions like electrolyte conductivity, flow rate, parallel vs series configurations, etc. The main advantage of theoretical modelling to address the topic of 3D electrodes is to allow comparison of a very wide range of electrode designs. The theoretical approach saves time and resources compared to a purely experimental approach.

The modelling approach can indeed establish relationship between the geometry of the reactor, its performance and values of operating input variables [13]. Gadkari et al. [14] have shown for example

\footnotetext{
* Corresponding author.

E-mail address: remy.lacroix@6t-mic.com (R. Lacroix).
} 
through a modelling approach that the performance of a microbial fuel cell (with a graphite fiber brush anode and an air cathode) was not affected significantly when $60 \%$ of the brush is removed, as reaction rate on anode area far from the cathode is much lower than reaction rate in anode area near the cathode. Similar calculations have been performed, validated with experimental data, which provided better understanding regarding the influence of temperature $\left(20-40{ }^{\circ} \mathrm{C}\right)$ on the performance of microbial fuel cell [15]. Hernández-García et al. [16], modelling a reactor with a cylindrical cathode around a packed bed of 95 carbon felt blocks, have demonstrated that anodic reaction rate is higher in the outer edges of the carbon bed compared to the center, and that "dead zones" are present in the reactor (low flow velocity) due to the dimensions and positioning of the inlet and outlet. Reyes-Vidal et al. [17] have studied numerically the impact of the implementation of fluid distributors at the inlet and outlet on the performance of a bioelectrochemical reactor applied for wastewater treatment. Finally, Oliot et al. [18] have also used a modelling approach to compare the performance of various bioelectrochemical systems.

In this work, a 3D multiphysics model was designed to simulate the current generation and resulting hydrogen production in double and triple-compartment MECs fed continuously with dWW. This model demonstrated the improvement obtained by replacing a 2D plate graphite electrode with a 3D geometry of graphite electrode, both in terms of COD removal in the dWW (anode compartment) and hydrogen production (cathode compartment). The optimal pore size of the 3D electrode geometry was considered to be several millimetres, to allow high microbial colonisation while avoiding obstruction and transport limitations in the pores [12]. The increase of hydrogen production by the installation of a second cathodic compartment is also established. The performance of the MEC have been calculated with a constant cell voltage of $1.0 \mathrm{~V}$, as this value allows hydrogen production at a much lower cost than conventional water electrolysis [19]. This cell voltage value has already been widely used on many studies on MEC reactors [20-24].

Multiphysics modelling coupling rheological, mass transfer and electrochemical phenomena is performed considering a continuously flow of dWW in the anodic compartment, with an ion exchange membrane separating the anodic and cathodic compartments. The continuous process is chosen as it is what is implemented in dWW treatment plants. For the cathode compartment, we consider a batch mode operation of the catholyte. The catholyte is an aqueous solution of $200 \mathrm{mmol}$ $\mathrm{L}^{-1}$ of $\mathrm{KHCO}_{3}$ already known to catalyse the $\mathrm{H}_{2}$ evolution reaction at $\mathrm{pH}$ close to neutrality and on stainless steel electrodes [19,25-27]. As anolyte and catholyte have a different composition, the use of a membrane is required in order to minimize catalytic $\mathrm{HCO}_{3}^{-}$ions transfer from the cathodic to the anodic compartment. A cation exchange membrane is considered in this study. Chemical Oxygen Demand (COD, $\mathrm{mg} \mathrm{L}^{-1}$ ) is usually used to describe the organic pollutant load in wastewater. We consider a COD value of $500 \mathrm{mg} \mathrm{L}^{-1}$ in the dWW flow at the inlet of the reactor, which is representative of dWW [21].

\section{Materials and methods}

\subsection{Software}

Modelling is performed with the COMSOL Multiphysics ${ }^{\circledR}$ v5.4 software. Three different modules are used: the laminar flow module, the secondary potential and current distribution module and the diluted concentration module. This software is widely adopted to model electrochemical systems at macroscopic scale such as polymer electrolyte membrane electrolyser [28,29], solid oxide fuel cells $[30,31]$ or batteries [32-34]. The approach considered in the present study has already been implemented for modelling MEC [35-38]. Triangular meshes are chosen for all geometries considered here. The geometry of all the MEC components (anodic compartment, membrane, cathodic compartment and electrodes) are defined in three dimensions.

\subsection{Rheology modelling}

The Reynolds number is calculated in the anodic compartment in order to select appropriate rheological equations. Equivalent diameter is used for the rectangular section [39] in the anodic compartment as well as in the dWW inlet and outlet tubes. A Reynolds numbers of 0.35 and 2.2 are respectively calculated in the rectangular section and in the dWW inlet/outlet tubes. The laminar flow module for a Newtonian Fluid is therefore used (Re " 2000), which solves Eqs. (1) and (2):

$\rho\left(\frac{\partial u}{\partial t}+u \cdot \nabla u\right)=-\nabla p+\nabla \cdot\left(\mu\left(\nabla u+(\nabla u)^{T}\right)-\frac{2}{3} \mu(\nabla \cdot u) I\right)+\mathrm{F}$

and

$\rho \nabla \cdot(u)=0$

with $\rho$ : fluid density $\left(\mathrm{kg} \mathrm{m}^{-3}\right), u$ : fluid velocity $\left(\mathrm{m} \mathrm{s}^{-1}\right), p$ : pressure (Pa) and $\mu$ : fluid viscosity (Pa.s). Values of water density $\left(1000 \mathrm{~kg} \mathrm{~m}^{-3}\right)$ and viscosity $\left(10^{-3} \mathrm{~Pa} \mathrm{~s}\right)$ at room temperature are used for dWW.

\subsection{Current and potential distribution modelling}

The secondary current distribution module is used in this study as already detailed in literature [35]. The distribution of the electrostatic potential was obtained by solving the Laplace equation (Eq. (3)):

$\Delta \Phi=0$

Then, the local current values are extracted from the map of the electrostatic potentials by using the Ohm's law in the electrode domains (bioanode and cathode, Eq. (4)):

$i_{s}=-\sigma_{s} \nabla \varphi_{s}$

with $\sigma_{S}$ : solid phase conductivity $\left(\mathrm{S} \mathrm{m}^{-1}\right), \varphi_{s}$ : electrostatic electrode potential $(\mathrm{V})$ and $i_{s}$ : electrode current density $\left(\mathrm{A} \mathrm{m}^{-2}\right)$.

The Ohm's law is also applied to electrolytes in the anolyte and catholyte compartments (Eq. (5)):

$i_{L}=-\sigma_{L} \nabla \varphi_{L}$

with $\sigma_{L}$ : liquid phase conductivity $\left(\mathrm{S} \mathrm{m}^{-1}\right), \varphi_{L}$ : electrostatic electrolyte potential $(\mathrm{V})$ and $i_{L}$ : electrolyte current density $\left(\mathrm{A} \mathrm{m}^{-2}\right)$.

The membrane separating the two compartments was considered as a liquid phase with a conductivity depending on the liquid phase volume fraction in this domain (Eqs. (6) and (7)).

$i_{M}=-\sigma_{\text {membrane }} \nabla \varphi_{M}$

$\sigma_{\text {membrane }}=\left(\varepsilon_{L, m}\right)^{1.5} \sigma_{L}$

With $i_{M}$ : current density through the membrane $\left(\mathrm{A} \mathrm{m}^{-2}\right), \sigma_{\text {membrane }}$ : membrane conductivity $\left(\mathrm{S} \mathrm{m}^{-1}\right), \varphi_{M}$ : membrane liquid phase potential (V) $\sigma_{L}$ : electrolyte conductivity $\left(\mathrm{S} \mathrm{m}^{-1}\right)$ and $\varepsilon_{L, m}$ : liquid volume fraction in the membrane (dimensionless).

Values for electrical conductivities and membrane porosity chosen as

Table 1

List of values for electrode, electrolyte and membrane conductivities and membrane porosity.

\begin{tabular}{llll}
\hline Parameter & Domain & Value & Reference \\
\hline$\sigma_{s}$ & Cathode (stainless & $1.3510^{6}$ & {$[40]$} \\
& steel) & $\mathrm{S} \mathrm{m}^{-1}$ & \\
$\sigma_{s}$ & Bioanode (graphite) & $8.310^{4} \mathrm{~S} \mathrm{~m}^{-1}$ & $\begin{array}{l}\text { Value provided by the } \\
\text { supplier }\end{array}$ \\
& Catholyte & $2.0 \mathrm{~S} \mathrm{~m}^{-1}$ & Measured \\
$\sigma_{L}$ & Anolyte & $0.1 \mathrm{~S} \mathrm{~m}^{-1}$ & Measured \\
$\sigma_{L}$ & Membrane & 0.5 & $\begin{array}{l}\text { Membrane technical } \\
\text { datasheet }\end{array}$ \\
$\varepsilon_{L, m}$ & & & \\
\hline
\end{tabular}


input values (Eqs. (4)-(7)) are summarized in Table 1.

On the cell wall, the boundary condition expresses that no electrochemical reaction occurs. On the electrode surfaces, the boundary conditions are given by electrochemical kinetics. Cathode and bioanode kinetics are determined experimentally using a 3-electrode set-up, with minimal distance between the working and the reference electrodes in order to avoid inaccuracies caused by the ohmic drop in the liquid phase $[41,42]$. For this reason, experimental kinetics are thoroughly determined with working electrodes of small surface area, about $2-3 \mathrm{~cm}^{2}$, in non-limited conditions.

\subsection{Kinetic of the cathodic reaction}

The cathodic reaction is the hydrogen evolution on $316 \mathrm{~L}$ stainless steel plain electrode catalysed by $\mathrm{KHCO}_{3}$ in solution [19]. The kinetic for this reaction is measured in a three-electrode electrochemical cell $(150 \mathrm{~mL})$, with a $316 \mathrm{~L}$ stainless steel plate $(15 \mathrm{~mm} \times 20 \mathrm{~mm} \times 2 \mathrm{~mm})$ as working electrode, a DSA as counter electrode (15 mm $\times 20 \mathrm{~mm} \times 2 \mathrm{~mm}$ ) and a saturated calomel reference electrode (SCE). The SCE potential is $0.24 \mathrm{~V}$ shifted from SHE. The electrolyte is a $200 \mathrm{mmol} \mathrm{L}^{-1} \mathrm{KHCO}_{3}$ aqueous solution ( $\mathrm{pH}$ of 8.3) prepared by dissolving lab-grade potassium bicarbonate in deionized water. Before the experiment, the stainless steel electrode was grounded with abrasive discs (P800, P1200, P2400; Presi). No chemical treatment was applied to the electrodes. The current collectors for both working and counter electrodes were threaded titanium rods insulated along their length with heat shrinkable tube. Experiments were performed at room temperature.

\subsection{Kinetic of the anodic reaction}

The anodic reaction is the electrochemical oxidation of the organic matter from dWW catalysed by the electroactive biofilm. The kinetic of the anodic bioelectrochemical reaction is measured in a three-electrode electrochemical cell, with a graphite plate as working electrode, a $316 \mathrm{~L}$ stainless steel grid as counter electrode $(15 \mathrm{~cm} \times 3 \mathrm{~cm}$ arranged in a circular shape) and a SCE reference electrode. The anode was prepared by coating $20 \mathrm{~mm} \times 20 \mathrm{~mm} \times 5 \mathrm{~mm}$ graphite plates with insulating varnish and drilling a hole of $1 \mathrm{~cm}$ diameter in the center of the electrode. The active area (covered by an electroactive biofilm) is $1.57 \mathrm{~cm}^{2}$. The electrolyte is dWW circulating in the loop that includes the threeelectrode electrochemical cell $(600 \mathrm{~mL})$ and a dWW storage tank $(2 \mathrm{~L})$ [43]. The dWW used for those measurements was taken from the aeration tank of the Castanet-Tolosan (France) sewage treatment plant. The conductivity for this source is typically $0.1 \mathrm{~S} . \mathrm{m}^{-1}$, with a $\mathrm{pH}$ value of $7.2 \pm 0.8$. Linear sweep voltammetry measurement is performed at room temperature in the electrode potential range from -0.5 to $+0.2 \mathrm{~V}$ vs SCE with a scan rate of $1 \mathrm{mV} . \mathrm{s}^{-1}$ when a steady state current had been observed after 24 days of working electrode polarization at $-0.1 \mathrm{~V}$ vs SCE. Chemical Oxygen Demand (COD) was measured using the Hach Lange LCK 514 microkits for a concentration ranging from 100 to $2000 \mathrm{mg}$ of $\mathrm{O}_{2}$. $\mathrm{L}^{-1}$ and LCK 314 for concentrations ranging from 15 to $150 \mathrm{mg}$ of $\mathrm{O}_{2} . \mathrm{L}^{-1}$. Membrane filtration $(0.2 \mu \mathrm{m}$, Minisart R PES, Sartorius) was performed before measurement.

\subsection{Organic matter transport}

Acetate is used as model molecule representative of organic matter in $\mathrm{dWW}$. The transport of organic matter to the bioanode/anolyte interface is considered by taking into account convection and diffusion in stationary mode (Eqs. (8) and (9)):

$\nabla \cdot\left(-D_{i} \nabla c_{i}\right)+u \cdot \nabla c_{i}=R i$

and

$N_{i}=-D_{i} \nabla c_{i}+u c_{i}$ with $\mathrm{D}_{\mathrm{i}}$ : diffusion coefficient for the organic matter $\left(1.0910^{-9} \mathrm{~m}^{2} \mathrm{~s}^{-1}\right.$ [44]), $c_{\mathrm{i}}$ : organic matter model molecule concentration $\left(\mathrm{mol} \mathrm{m}^{-3}\right), \mathrm{R}_{\mathrm{i}}$ : organic matter consumption/production in the bulk $\left(\mathrm{mol} \mathrm{m}^{-3} \mathrm{~s}^{-1}\right)$, u: fluid velocity $\left(\mathrm{m} \mathrm{s}^{-1}\right)$ and $\mathrm{Ni}$ : organic matter flow $\left(\mathrm{mol} \mathrm{m}^{-2} \mathrm{~s}^{-1}\right)$.

At the interface between the bioanode and the anolyte, the local organic matter degradation rate is directly related to the current density $\left(\mathrm{A} \mathrm{m}^{-2}\right)$, as expressed in Eq. (10):

$Q_{\text {OM }}=\frac{J_{\text {Bioanode }}}{n F}$

With: $J_{\text {Bioanode: }}$ bioanodic current density $\left(\mathrm{A} \mathrm{m}^{-2}\right), n$ : number of electrons involved in the organic matter oxidation reaction (8 moles of electron per mole of acetate), $F$ : Faraday constant $\left(96,485 \mathrm{C} \mathrm{mol}^{-1}\right)$ and Qom: organic matter model molecule consumption rate by the electroactive biofilm ( $\mathrm{mol} \mathrm{m}^{-2} \mathrm{~s}^{-1}$ ).

Acetate was chosen as a model organic molecule as it is frequently used as model substrate to feed MFC and MEC [45]. The choice of another model molecules such as arabitol $\left(\mathrm{C}_{5} \mathrm{H}_{12} \mathrm{O}_{5}\right)$, ethanol $\left(\mathrm{C}_{2} \mathrm{H}_{6} \mathrm{O}\right)$, glucose $\left(\mathrm{C}_{6} \mathrm{H}_{12} \mathrm{O}_{6}\right)$, sucrose $\left(\mathrm{C}_{12} \mathrm{H}_{22} \mathrm{O}_{11}\right)$ or tert-Butanol $\left(\mathrm{C}_{4} \mathrm{H}_{10} \mathrm{O}\right)$ would have led to almost identical results as these molecules have similar diffusion coefficients $\left(0.49-1.2310^{-9} \mathrm{~m}^{2} \mathrm{~s}^{-1}\right)$ [46]. Regarding organic matter consumption by the anodic reaction, no detailed analysis of dWW composition and which organic molecules are consumed by the electroactive biofilm has been performed, due to complexity of the task and the required procedures and analytical equipment. However, the data used as input in the modelling (consumption of organic matter by the electroactive biofilm and impact on the COD in the liquid phase) are based on experimental results.

\subsection{Calculation of COD removal and hydrogen production rates}

COD in the anolyte (used to describe the organic pollutant load in dWW) is calculated by COMSOL Multiphysics ${ }^{\circledR}$. COD is proportional to the model molecule concentration, with $64 \mathrm{~g}$ of COD being the equivalent of $1 \mathrm{~mol}$ of acetate. COD removal yield performed by the MEC is calculated using Eq. (11):

COD Removal Yield $=1-\frac{F_{C O D(\text { outlet })}}{F_{C O D(\text { inlet })}}$

With $F_{C O D(o u t l e t)}$ : organic matter (COD) flow at the reactor outlet

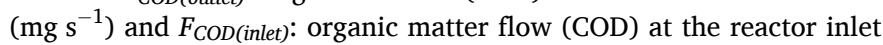
$\left(\mathrm{mg} \mathrm{s}^{-1}\right)$.

The hydrogen production rate is calculated with Eqs. (16) and (17):

$\operatorname{Qmol}\left(H_{2}\right)=\frac{i}{n F}$

$\operatorname{PQvol}\left(\mathrm{H}_{2}\right)=\operatorname{Qmol}\left(\mathrm{H}_{2}\right) R T$

With $\operatorname{Qmol}\left(\mathrm{H}_{2}\right)$ : Standard molar hydrogen production rate $\left(\mathrm{mol} \mathrm{s}^{-1}\right)$, $i$ : current (A), $n$ : number of electrons involved in the hydrogen evolution reaction (2, unitless) and $F$ : Faraday constant $\left(96,485 \mathrm{C} \mathrm{mol}^{-1}\right), P$ : standard pressure $\left(10^{5} \mathrm{~Pa}\right), R$ : perfect gas constant $\left(8.314 \mathrm{~J} \mathrm{~mol}^{-1} \mathrm{~K}^{-1}\right)$ and $T$ : standard temperature $(273.15 \mathrm{~K})$.

\subsection{Definition of the geometry of the system}

A first modelling study is performed to evaluate the benefit provided by 3 geometries of 3D macroporous bioanodes compared to 2D graphite plate bioanode in a parallelepiped dual chamber MEC reactor. The anodic compartment dimensions are $60 \mathrm{~mm} \times 110 \mathrm{~mm} \times 110 \mathrm{~mm}$. The cathodic compartment dimensions are $20 \mathrm{~mm} \times 110 \mathrm{~mm} \times 110 \mathrm{~mm}$. A membrane with dimensions $110 \mathrm{~mm} \times 110 \mathrm{~mm}$ separates anodic and cathodic compartments. The distance between the bioanode and the membrane is $5 \mathrm{~mm}$, the distance between the membrane and the cathode is $10 \mathrm{~mm}$. The overall current is calculated for the four bioanode geometries precisely described as: 
- a 2D bioanode made with a solid graphite plate of $100 \mathrm{~mm}$ length, $100 \mathrm{~mm}$ width and $2 \mathrm{~mm}$ thickness (Fig. 1A) leading to a total developed surface area of $208 \mathrm{~cm}^{2}$.

- and three 3D graphite bioanodes with the same projected surface area (length of $100 \mathrm{~mm}$ and a width of $100 \mathrm{~mm}$ ) and variable thicknesses ranging from 2 to $40 \mathrm{~mm}$, in which have been machined:

○ 9 square holes of $30 \mathrm{~mm} \times 30 \mathrm{~mm}$ leading to a total anodic developed surface area of $630 \mathrm{~cm}^{2}$ for an electrode thickness of $40 \mathrm{~mm}$ (Fig. 1B);

- 16 square holes of $20 \mathrm{~mm} \times 20 \mathrm{~mm}$ leading to a total anodic developed surface area of $744 \mathrm{~cm}^{2}$ for an electrode thickness of 40 mm (Fig. 1C);

- 64 square holes of $10 \mathrm{~mm} \times 10 \mathrm{~mm}$ leading to a total anodic developed surface area of $1256 \mathrm{~cm}^{2}$ for an electrode thickness of $40 \mathrm{~mm}$ (Fig. 1D).

Note here that the real projected surface area is always $100 \mathrm{~cm}^{2}$ for all the electrodes.

The geometry of the 3D bioanode is then modified in order to generate a convective transport of the organic matter in the porous structure of the electrode, thus increasing the overall bioanode current (Fig. 2E). The geometry of the $20 \mathrm{~mm}$ thick monolithic (single piece) 3D bioanode is replaced by a geometry of three stacked electrodes of $5 \mathrm{~mm}$ thickness each. The improvement of the convective organic matter transport is primarily based on a more homogeneous penetration and distribution of the hydrodynamic flow in the porosity of the 3D electrode. Equal spacing is set between the reactor wall and the bioanode external surface, between the three bioanode part and between the third bioanode part and the membrane. The implementation of a second cathodic compartment is also studied to decrease the distance between the 1st part of the bioanode and the nearest cathode (Fig. 2F).

\subsection{List of parameters and performance evaluation}

Table 2 summarizes and details the values of parameters used in this modelling study for "standard conditions" as well as in others conditions.

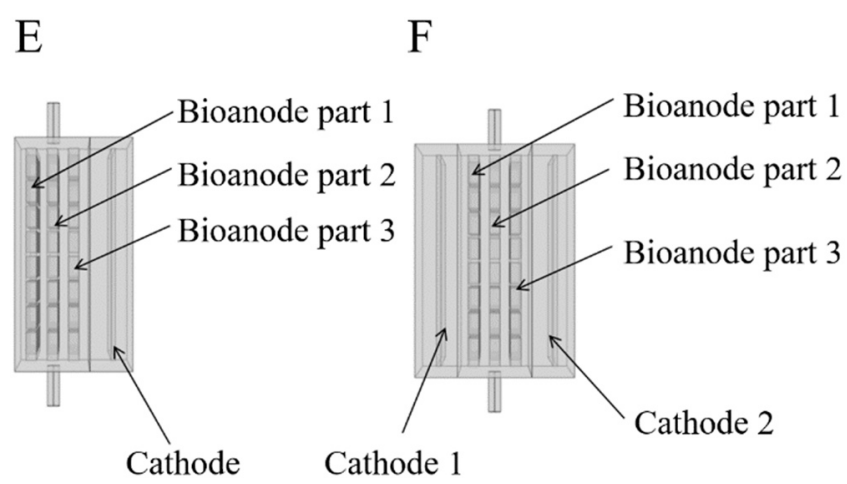

Fig. 2. Replacement of a monolithic bioanode by a three parts electrode (configuration E) and implementation of a second cathodic compartment (configuration F).

Table 2

Values of cell voltage, residence time, organic matter concentration (COD), bioanode thickness and number of cathodic compartments considered in this study.

\begin{tabular}{|c|c|c|c|}
\hline Parameter & Symbol & $\begin{array}{l}\text { Value in standard } \\
\text { conditions }\end{array}$ & $\begin{array}{l}\text { Range conditions for } \\
\text { parametric study }\end{array}$ \\
\hline Cell voltage & $\mathrm{U}$ & $1 \mathrm{~V}$ & $1 \mathrm{~V}$ \\
\hline Residence time & $\tau$ & $8 \mathrm{~h}$ & $1 \mathrm{~h}, 8 \mathrm{~h}, 24 \mathrm{~h}$ \\
\hline $\begin{array}{l}\text { COD in the reactor } \\
\text { inlet }\end{array}$ & COD & $500 \mathrm{mg} \cdot \mathrm{L}^{-1}$ & $500 \mathrm{mg} \mathrm{L}^{-1}$ \\
\hline $\begin{array}{l}\text { Bioanode projected } \\
\text { surface }\end{array}$ & NA & $100 \mathrm{~cm}^{2}$ & $100 \mathrm{~cm}^{2}$ \\
\hline Bioanode thickness & NA & $\begin{array}{l}20 \mathrm{~mm} \text { (one part } \\
\text { bioanode) }\end{array}$ & $\begin{array}{l}2,5,10,20,30 \text { and } \\
40 \text { mm (one part } \\
\text { bioanode) } \\
5 \mathrm{~mm} \times 3 \text { (three parts } \\
\text { bioanode) }\end{array}$ \\
\hline $\begin{array}{l}\text { Number of cathodic } \\
\text { compartments }\end{array}$ & NA & 1 & 1 and 2 \\
\hline
\end{tabular}

Various configuration performances are evaluated by considering three results: the COD removal yield between the inlet and outlet, the current and the corresponding hydrogen evolution rate.

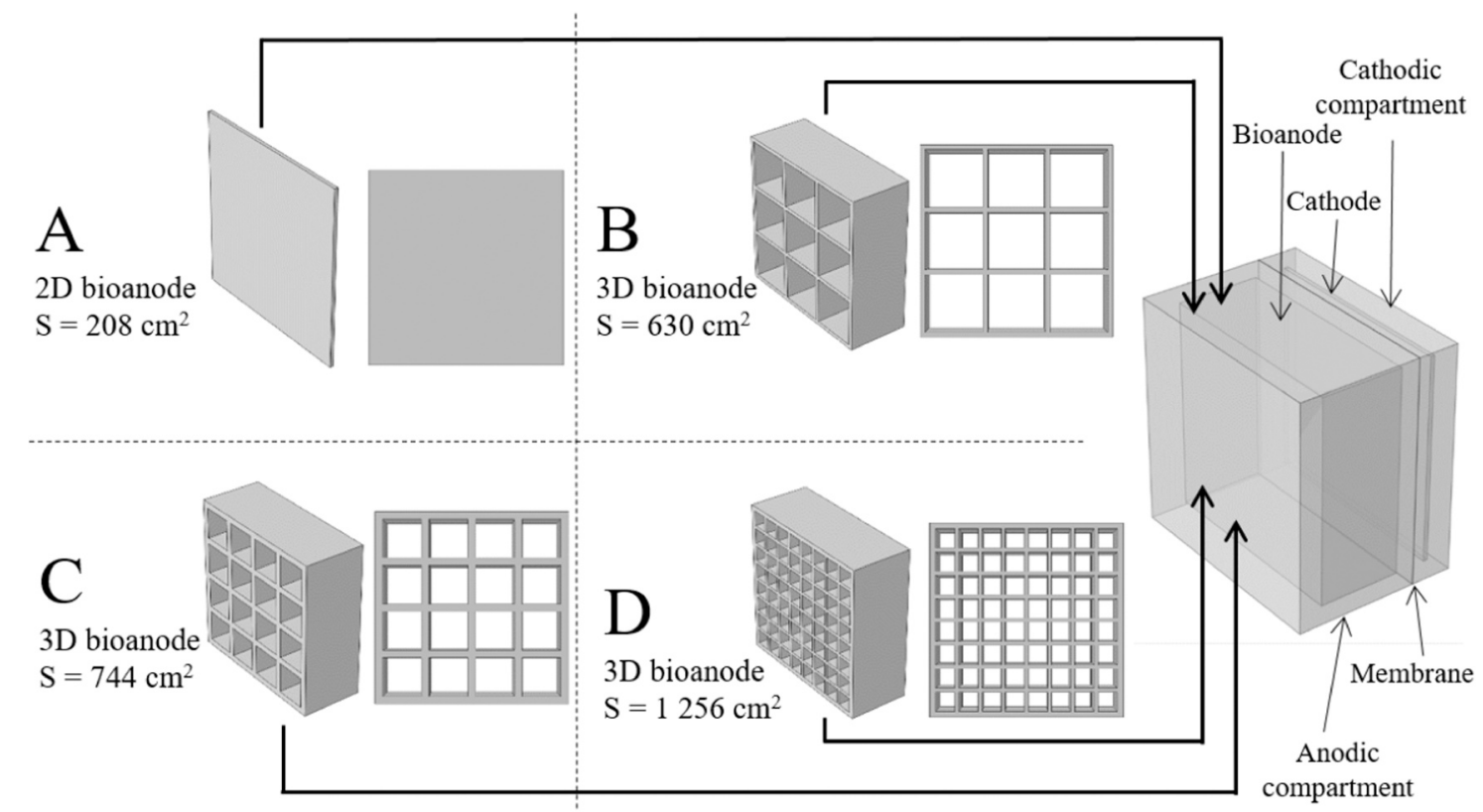

Fig. 1. Definition of the geometry of the system for configurations A, B, C and D. 


\section{Results and discussion}

\subsection{Kinetic of the cathodic reaction}

Experimental protocol for the measurement of the cathodic reaction kinetic is detailed in Section 2.4 of this report. A Butler-Volmer equation (Eqs. (14) and (15)) is used to fit experimental data with the parameters listed in Table 3.

$J_{\text {cath }}=J_{0}\left(\exp \left(\frac{\alpha_{a} F \eta}{R T}\right)-\exp \left(\frac{\alpha_{c} F \eta}{R T}\right)\right)$

With

$\eta=E-E_{\text {ocp }}$

Comparison of Butler-Volmer theoretical curve and experimental data is provided in Appendix A. Good agreement is obtained between the theoretical and experimental curves.

\subsection{Kinetic of the bioanodic reaction}

Experimental protocol for the measurement of the bioanodic reaction kinetic is detailed in Section 2.5. The experimental kinetics is fitted by Michaelis-Menten law (Eq. (16)) which links the dependence of the kinetics on the COD. This equation (Eq. (16)) is coupled with a NernstMichaelis-Menten law (Eq. (17)), also improperly named Nernst-Monod, which expresses the dependence of the kinetics with respect to the electrode potential.

$J_{M M}=\frac{J_{\max } x c}{K_{m}+c}$

And

$J_{\text {bioanode }}=\frac{J_{M M}}{1+e^{\frac{-F\left(E_{a n}-E_{1 / 2}\right)}{R T}}}$

The optimal parameters resulting from numerical fitting of Eqs. (16) and (17) are listed in Table 4. This combined equation is used as boundary condition at the bioanode surface.

A good agreement between theoretical and experimental curve is obtained for both COD value (Appendix B). The plateau observed for bioanode potential above $-0.25 \mathrm{~V}$ vs SCE are caused by limitations related to the metabolism of the electroactive biofilm and are consistent with literature measurements $[47,48]$.

\subsection{Influence of the bioanode thickness on the current}

The theoretical current produced for a cell voltage of $1.0 \mathrm{~V}$ is plotted in Fig. 3. for 2D electrode (configuration A) and 3D electrodes (configurations $\mathrm{B}, \mathrm{C}$ and $\mathrm{D}$ ).

Table 3

List of parameters introduced in the software for the kinetic of the cathodic reaction.

\begin{tabular}{lll}
\hline Parameter & Description & Value \\
\hline$J_{O}$ & Exchange current density & $0.14 \mathrm{~A} \mathrm{~m}^{-2}$ \\
$\alpha_{a}$ & $\begin{array}{l}\text { Anodic charge transfer } \\
\text { coefficient }\end{array}$ & 0.50 (unitless) \\
& $\begin{array}{l}\text { Cathodic charge transfer } \\
\alpha_{c}\end{array}$ & 0.20 (unitless) \\
& coefficient & \\
$F$ & Faraday constant & $96,485 \mathrm{C} \mathrm{mol}^{-1}$ \\
$R$ & Ideal gas constant & $8.314 \mathrm{~J} \mathrm{~mol}^{-1} \mathrm{~K}^{-1}$ \\
$T$ & Temperature & $293 \mathrm{~K}$ \\
$E_{\text {ocp }}$ & Open circuit potential (vs SCE) & $-0.5 \mathrm{~V}$ \\
$E$ & Electrode potential & Calculated by the software (V) \\
$\eta$ & Overpotential & Calculated by the software (V) \\
$J_{\text {cath }}$ & Cathodic current density & Calculated by the software \\
& & (A m ${ }^{-2}$ ) \\
\hline
\end{tabular}

Table 4

List of parameters for the kinetic of the anodic reaction.

\begin{tabular}{lll}
\hline Parameter & Description & Value \\
\hline Jmax & Maximum current density & $6.0 \mathrm{~A} \mathrm{~m}^{-2}$ \\
$K m$ & Michaelis constant & $20 \mathrm{~mol} \mathrm{~m}^{-3}$ \\
$c$ & Organic matter model molecule & $3.34 \mathrm{~mol} \mathrm{~m}^{-3}$ \\
& concentration & $\left(\mathrm{COD}=214 \mathrm{mg} \mathrm{L}^{-1}\right)$ \\
& & $9.14 \mathrm{~mol}^{-3}$ \\
& & $\left(\mathrm{COD}=586 \mathrm{mg} \mathrm{L}^{-1}\right)$ \\
$F$ & Faraday constant & $96,485 \mathrm{C} \mathrm{mol}^{-1}$ \\
$R$ & Perfect gas constant & $8.314 \mathrm{~J} \mathrm{~mol}^{-1} \mathrm{~K}^{-1}$ \\
$T$ & Temperature & $298 \mathrm{~K}$ \\
$E_{\text {an }}$ & Bioanode potential vs SCE & Calculated by the software \\
& & $(\mathrm{V})$ \\
$E_{1 / 2}$ & Bioanode potential (vs SCE) for which & $-0.33 \mathrm{~V}$ \\
& the current density equals $50 \%$ of the & \\
& maximum current density. & Calculated by the software \\
$J_{\text {Anode }}$ & Bioanodic current density & $($ A m \\
& &
\end{tabular}

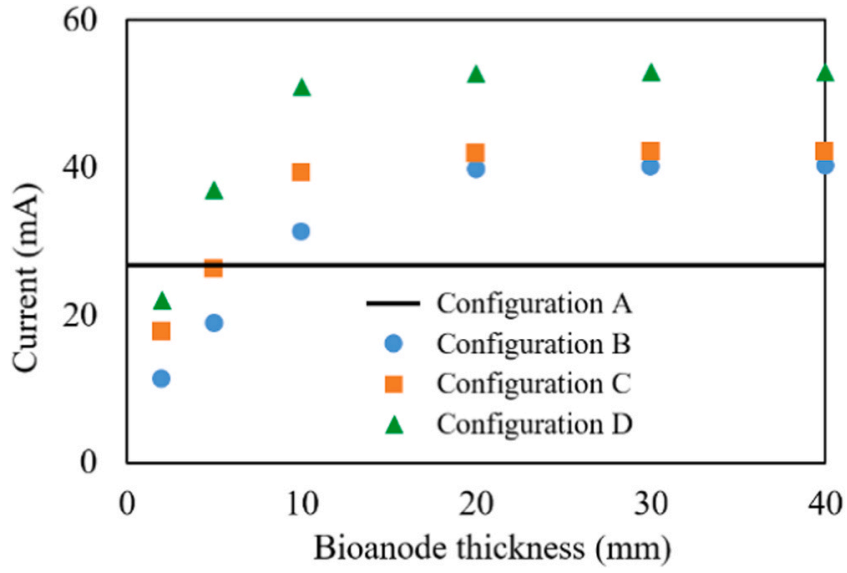

Fig. 3. Influence of the bioanode thickness for configurations $A, B, C$ and $D$ on the current for a cell voltage of $1 \mathrm{~V}$ and COD of $500 \mathrm{mg} \mathrm{L}^{-1}$ in the anolyte.

Results of electrolyte potential calculations for configurations A to D (with electrode thickness of $40 \mathrm{~mm}$ for configurations B, C and D) are provided in Appendix C. Fig. 3 shows that performances are better with 3D bioanodes compared to 2D bioanode only for electrode thickness above $10 \mathrm{~mm}$. For a thickness value of $5 \mathrm{~mm}$, the current is higher for the 2D electrode (configuration A, $26.9 \mathrm{~mA}$ ) compared to 3D electrodes (configuration $\mathrm{B}, \mathrm{C}$ and $\mathrm{D}$, currents of $11.4,17.8$ and $22.1 \mathrm{~mA}$ respectively). For a thickness of $20 \mathrm{~mm}$, the current is $80 \%$ higher for configuration D compared to configuration A. The size of the machined squares also has an impact on the current. For an bioanode thickness of $20 \mathrm{~mm}$, current is higher for configuration $\mathrm{D}(52.7 \mathrm{~mA}$, size of the squares holes: $10 \mathrm{~mm})$ compared to configuration C $(41.9 \mathrm{~mA}$, size of squares holes: $20 \mathrm{~mm}$ ) and configuration $\mathrm{B}(39.8 \mathrm{~mA}$, size of square holes: $30 \mathrm{~mm}$ ).

Fig. 3. shows clearly current produced by a $3 \mathrm{D}$ electrode is not proportional to area of contact between the electrode and electrolyte. This is caused by the fact that model takes into account not only the bioanode area but also the field line penetration inside the bioanode pores. Bioanode areas far from the cathode or masked are less active than areas near the cathode due to the low ionic conductivity of dWW $\left(0.1 \mathrm{~S} \mathrm{~m}^{-1}\right)$. This phenomenon caused by low anolyte ionic conductivity is not observed in MEC using highly saline anolyte [10,36,49]. This phenomenon is also generally negligible in bioelectrochemical systems for ionic conductivity above $0.2 \mathrm{~S} \mathrm{~m}^{-1}$ for low current densities $\left(<0.1 \mathrm{~A} \mathrm{~m}^{-2}\right)[50]$. 


\subsection{Hydrodynamic behaviour}

The dWW velocity profile in the bioanode compartment (configuration $\mathrm{D}$ ) for a hydraulic residence time of $8 \mathrm{~h}$ is provided in Appendix $\mathrm{D}$. A residence time of $8 \mathrm{~h}$ is characteristic of processes in the domestic wastewater treatment industry. The pressure drop between the anodic compartment inlet and outlet is barely negligible $(<1 \mathrm{~Pa})$, due to low anolyte velocity (high residence time), low reactor height $(11 \mathrm{~cm})$ and low dWW viscosity $\left(10^{-3}\right.$ Pa.s). Results of the hydrodynamic flow simulation showed clearly the main pathway for the anolyte flow occurs in the areas between the reactor wall and the electrode, and not within the 3D electrode structure. Calculations with residence time values of $1 \mathrm{~h}$ and $24 \mathrm{~h}$ showed similar results in terms of major pathways for the fluid flow and low pressure drop values between the inlet and outlet. In all cases, the flow occurs around the electrodes rather than within the pores and pressure drop values are $5.410^{-3} \mathrm{~Pa}(\tau=24 \mathrm{~h}), 1.610^{-2} \mathrm{~Pa}$ $(\tau=8 \mathrm{~h})$ and $1.310^{-1} \mathrm{~Pa}(\tau=1 \mathrm{~h})$.

\subsection{Results obtained in standard conditions}

COD profile in the anodic compartment is calculated (Fig. 4) for configuration D with the standard conditions defined in Table 2 in steady state.

The steady state is theoretically obtained for an infinite time after reactor start-up and biofilm stabilization. In practice this corresponds to results obtained after 3-10 times the residence time value (thereafter $24-80 \mathrm{~h}$ ) of reactor operation with a stable biofilm. The calculated current is $28.1 \mathrm{~mA}$ corresponding to a $\mathrm{H}_{2}$ production rate of 286 standard $\mathrm{mL}$ per day.

COD is strongly impacted by the proximity of the bioanode as it is consumed locally by the electroactive biofilm. The blueish colours (COD) are mostly found in the porosity of the bioanode. Within these pores COD is low because the transfer of organic matter (mostly by diffusion) is insufficient to compensate organic matter consumption by the EA biofilm (diffusional limitations regime). These diffusion limitations coupled with the ohmic drop in the liquid phase are responsible for strong heterogeneities of the anodic current density values on the

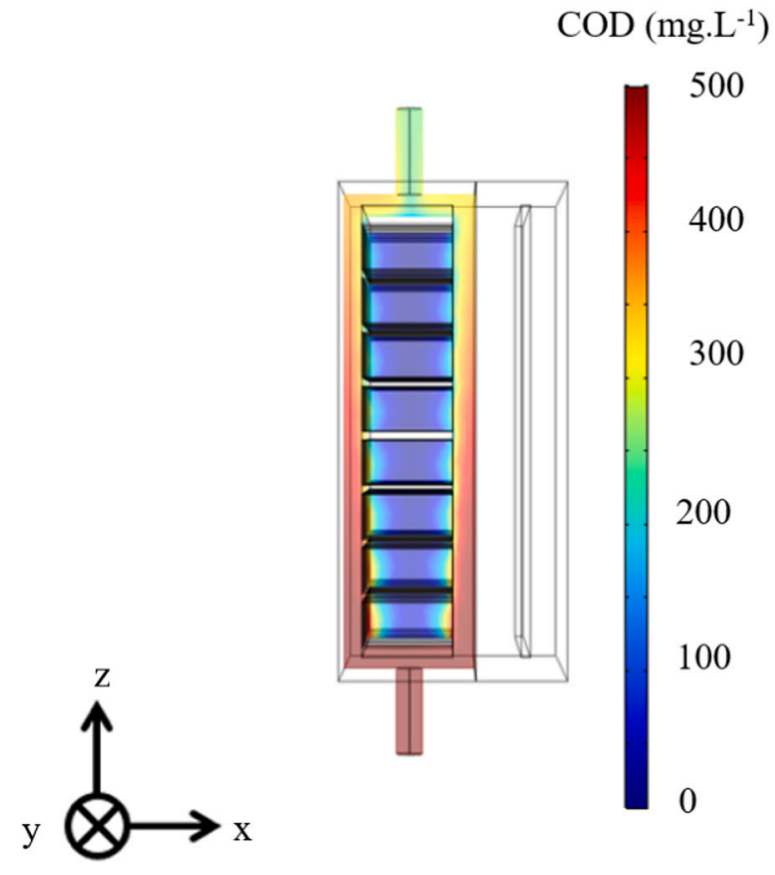

Fig. 4. Theoretical COD in the volume of the anodic compartment (configuration D) for a residence time of $8 \mathrm{~h}$, cell voltage of $1.0 \mathrm{~V}$, COD of $500 \mathrm{mg} \mathrm{L}^{-1}$ in the reactor inlet and bioanode thickness of $20 \mathrm{~mm}$. electrodes (Fig. 5).

The maximum local current density on the bioanode $\left(1.59 \mathrm{~A} \mathrm{~m}^{-2}\right)$ is located in the surface exposed to the cathode and close to the inlet for the continuous flow of dWW, where the organic matter concentration is the highest. In contrast, lowest values of current density are on the furthest anodic face in relation to the cathode position and within COD depleted zones in the bioanode pores. The total current generated by the bioanode is $28.0 \mathrm{~mA}$ corresponding to an average anodic current density of $0.42 \mathrm{~A} \mathrm{~m}^{-2}$ for the actual total surface electrode area $\left(664 \mathrm{~cm}^{2}\right)$ or $2.80 \mathrm{~A} \mathrm{~m}^{-2}$ considering the projected surface area $\left(100 \mathrm{~cm}^{2}\right)$.

\subsection{Results obtained when using a three parts bioanode}

Fig. 6. gives the COD profile for configuration $\mathrm{E}$ in the bioanode compartment with standard values for the residence time, COD in the reactor inlet and cell voltage (Table 2).

The use of three separate parts of stacked 3D bioanodes instead of a single monolithic 3D electrode resulted in a major change of organic matter concentration profile in the liquid phase. The electrical current generated by the three-part bioanode is also greatly improved $(33.5 \mathrm{~mA}$ or $3.35 \mathrm{~A} \mathrm{~m}^{-2}$ considering projected surface). This current value is $20 \%$ higher than the current initially calculated using the monolithic bioanode $(28.0 \mathrm{~mA})$. The overall COD removal increases proportionally and reaches a $61 \%$ of removal yield while it is only about $49 \%$ when the dWW treatment is carried out by the monolithic bioanode.

Fig. 7 describes the COD profiles for configuration E, along the hydrodynamic route of dWW from the bottom to the top (Y-axis) of the MEC anodic chamber, for four distinctive series of points (X-axis) as indicated precisely on the Fig:

- Series of points number 1 between the reactor wall and the 1st part of the bioanode

- Series of points number 2 between the1st and 2nd parts of the bioanode

- Series of points number 3 between the 2 nd and 3rd bioanode part

- Series of points number 4 between the 3rd bioanode part and the membrane

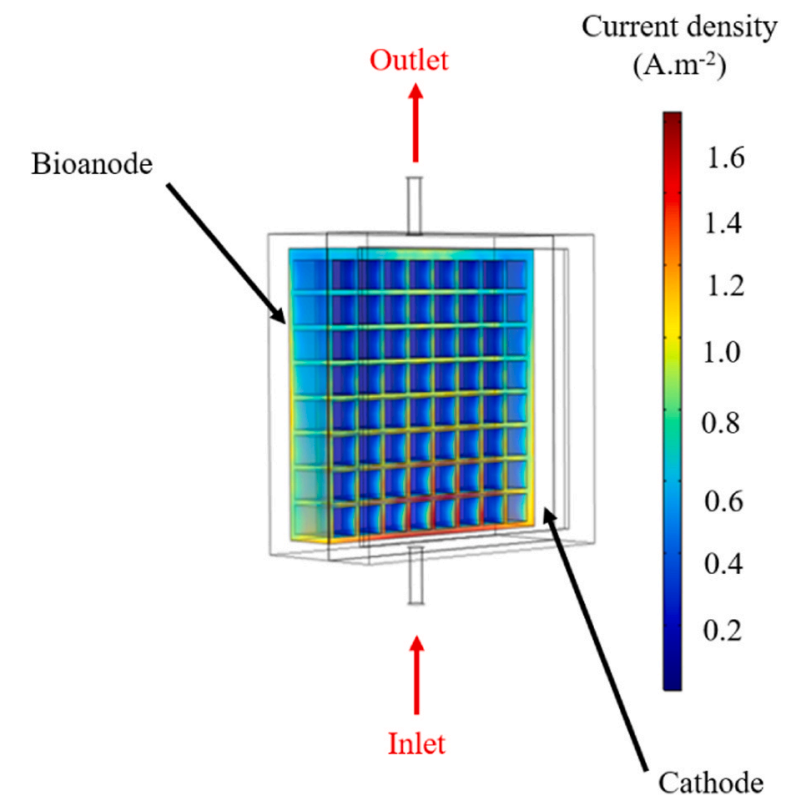

Fig. 5. Theoretical anodic current density (Configuration D) for a residence time of $8 \mathrm{~h}$, cell voltage of $1.0 \mathrm{~V}$, COD of $500 \mathrm{mg} \mathrm{L}^{-1}$ in the reactor inlet and an bioanode thickness of $20 \mathrm{~mm}$. (For interpretation of the references to colour in this figure, the reader is referred to the web version of this article.) 


\section{Configuration $\mathrm{E}$}

\section{Outlet}

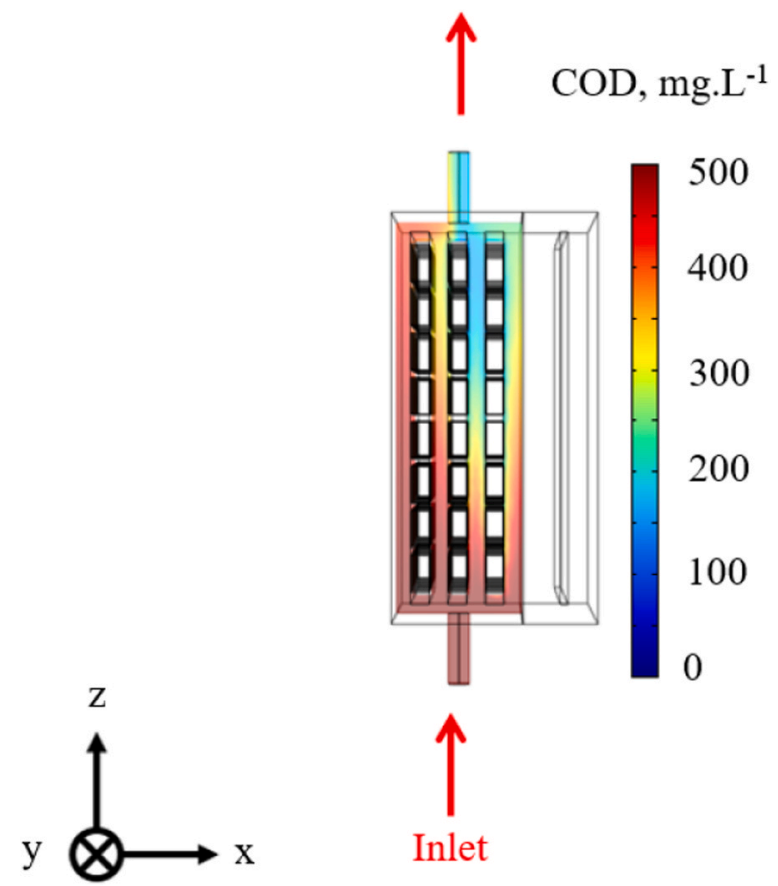

Fig. 6. Theoretical COD (configuration E) for a residence time of $8 \mathrm{~h}$, cell voltage of $1.0 \mathrm{~V}$, COD of $500 \mathrm{mg} \mathrm{L}^{-1}$ in the reactor inlet and bioanode thickness of $3 \times 5 \mathrm{~mm}$.

When the MEC operates in steady state i.e. produces a constant current COD is higher for series of points 1 and 3 compared to series 2 and 4. Most of COD removal occurs in the areas nearby the membrane and therefore closest to the cathode. This result is consistent with the calculation of current produced by each 3 parts of the electrode with values of $7.7 \mathrm{~mA}$ for part 1 (far from the cathode), $8.7 \mathrm{~mA}$ for part 2 (in the middle position) and $17.1 \mathrm{~mA}$ for part 3 (nearby the membrane). Differences are caused by a combination of two factors. Firstly, part 1 and part 2 of the bioanode (near the wall and in the middle) are less accessible for the electrical field lines compared to the third bioanode part. Secondly, significant ohmic drop occurs in the liquid phase due to the low dWW ionic conductivity $\left(0.1 \mathrm{~S} \mathrm{~m}^{-1}\right)$. It is therefore normal that bioanode areas far from the cathode are less active than areas near the cathode.

\subsection{Results after implementation of an additional cathodic compartment}

The use of a three-compartments reactor (configuration F) with two cathode compartments arranged on both sides of the bioanode compartment leads to a significant increase of the overall steady state current, which reached $39.5 \mathrm{~mA}$ for a three-chamber MEC design compared to the $33.5 \mathrm{~mA}$ expected from the dual-chamber MEC reactor design. The COD removal is also significantly increased accordingly with a $72 \%$ removal yield (configuration F) (Fig. 8) compared to $61 \%$ (configuration E).

Values of local COD are plotted for four distinct series of points (configuration F) in Fig. 9. COD are identical for series of points 1 and 4 as well as for series of points 2 and 3 for symmetry reasons.

The implementation of a second cathode compartment has a major impact on the concentration profile in the anolyte (Fig. 9). Higher COD removal is obtained with the implementation of an additional cathodic compartment, which means lower organic matter concentration in the four zones near the reactor outlet. COD removal is therefore much higher for the series of points 1 and 2 for configuration $\mathrm{F}$ compared to configuration $\mathrm{E}$.

Finally, calculations are performed with configuration $\mathrm{F}$ considering three values ( $1 \mathrm{~h}, 8 \mathrm{~h}$ and $24 \mathrm{~h}$ ) of residence time $\tau$ (Fig. 10).

Fig. 10 demonstrates that different strategies can be applied to operate the MEC technology depending on the pursued purpose. On one

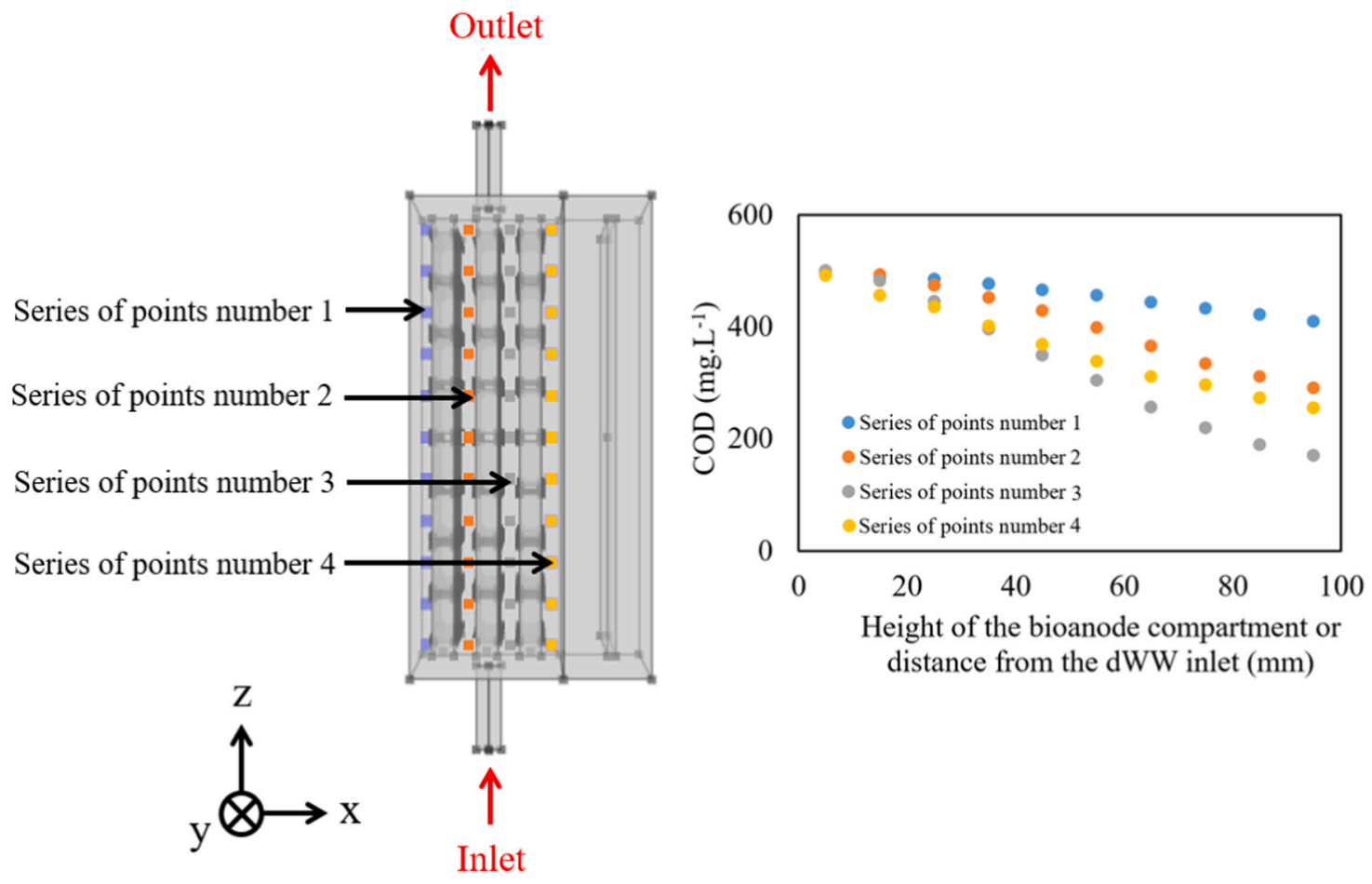

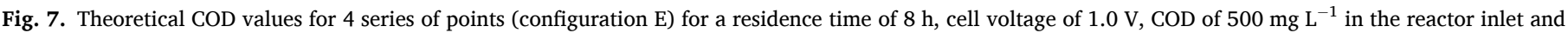
bioanode thickness of $3 \times 5 \mathrm{~mm}$. 


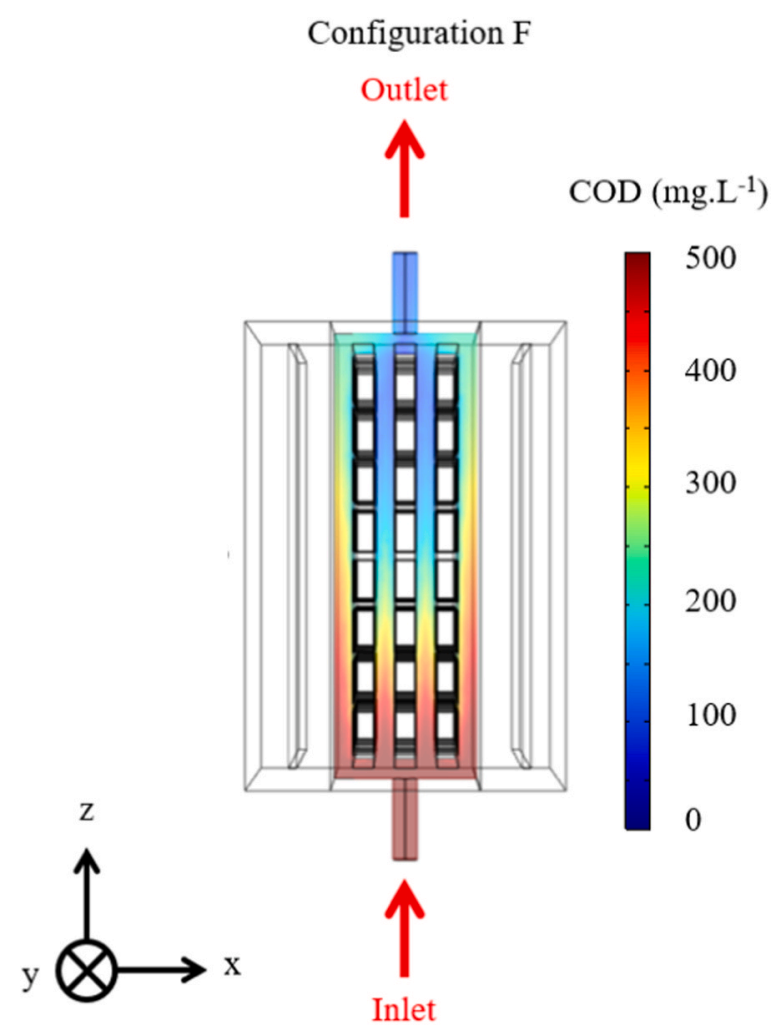

Fig. 8. Theoretical COD values for configuration $F$ for a residence time of $8 \mathrm{~h}$, cell voltage of $1.0 \mathrm{~V}$, COD of $500 \mathrm{mg} \mathrm{L}^{-1}$ in the reactor inlet and bioanode thickness of $3 \times 5 \mathrm{~mm}$.

hand, the increase of the $\tau$ in the anodic compartment can drastically improve the COD oxidation rate by the anodic biofilm, with COD removal yield of $25 \%$ for a $\tau$ of one hour, $78 \%$ for eight hours and $98 \%$ for twenty-four hours. On the other hand, the $\tau$ increase can decrease the overall current generation and therefore hydrogen production rate e.g.
756 standard $\mathrm{mL}$ per day $(\tau=1 \mathrm{~h}, \mathrm{i}=74.5 \mathrm{~mA}), 402$ standard $\mathrm{mL}$ per day $(\tau=8 \mathrm{~h}, \mathrm{i}=39.5 \mathrm{~mA})$ and 169 standard $\mathrm{mL}$ per day $(\tau=24 \mathrm{~h}$, $\mathrm{i}=16.6 \mathrm{~mA}$ ). Results regarding the influence of residence time on COD removal and current are consistent with literature data. Actually Guo et al. [51] measured performance obtained in 10 cells of a bioelectrochemical stack and current values obtained for dWW treatment are (on average) equals to $0.09 \mathrm{~mA}$ for a residence time of $6.3 \mathrm{~h}$ compared to $0.49 \mathrm{~mA}$ for a residence time of $0.63 \mathrm{~h}$. Similar results are also obtained in Microbial Fuel Cells. Moon et al. [52] also measured significant current increase with decreasing hydraulic residence time for various organic matter concentrations in the reactor inlet.

\section{Conclusion}

A 3D multiphysics model is built to evaluate and quantify the interest of different 3D electrode designs compared to conventional 2D plane electrodes. The performance increase caused by the change of the electrode geometry depends on the shape of the 3D structure as well as operating conditions. Current can be increased by over $83 \%$ with the proper geometry. The use of 3D bioanodes thicker than $20 \mathrm{~mm}$ is not interesting due to performance stagnation above this value. Moreover, the bioanode geometry shall be carefully designed in order to avoid limitations caused by organic matter or ions mass transport within the 3D bioanode structure. The use of stacked 3D anodic plates rather that a thick 3D electrode makes easier the transport of organic matter from the liquid phase to the bioanode surface (current increase by 20\%). Finally, the implementation of an additional cathodic compartment is an efficient strategy to increase performance further (current increases by an additional $20 \%$ ).

It should be noticed that the model considers a biofilm with a uniform electrochemical kinetics on the whole bioanode surface area. Actually, the local potential may affect the biofilm development and its electrocatalytic characteristics. It can be a cause of deviation between theoretical and experimental results particularly in electrolytes with low ionic conductivity [42]. The state of the art does not provide yet a simple relationship between the catalytic properties of the biofilm and the potential of the electrode on which it is formed. This would be a major avenue for progress to be considered for future research particularly

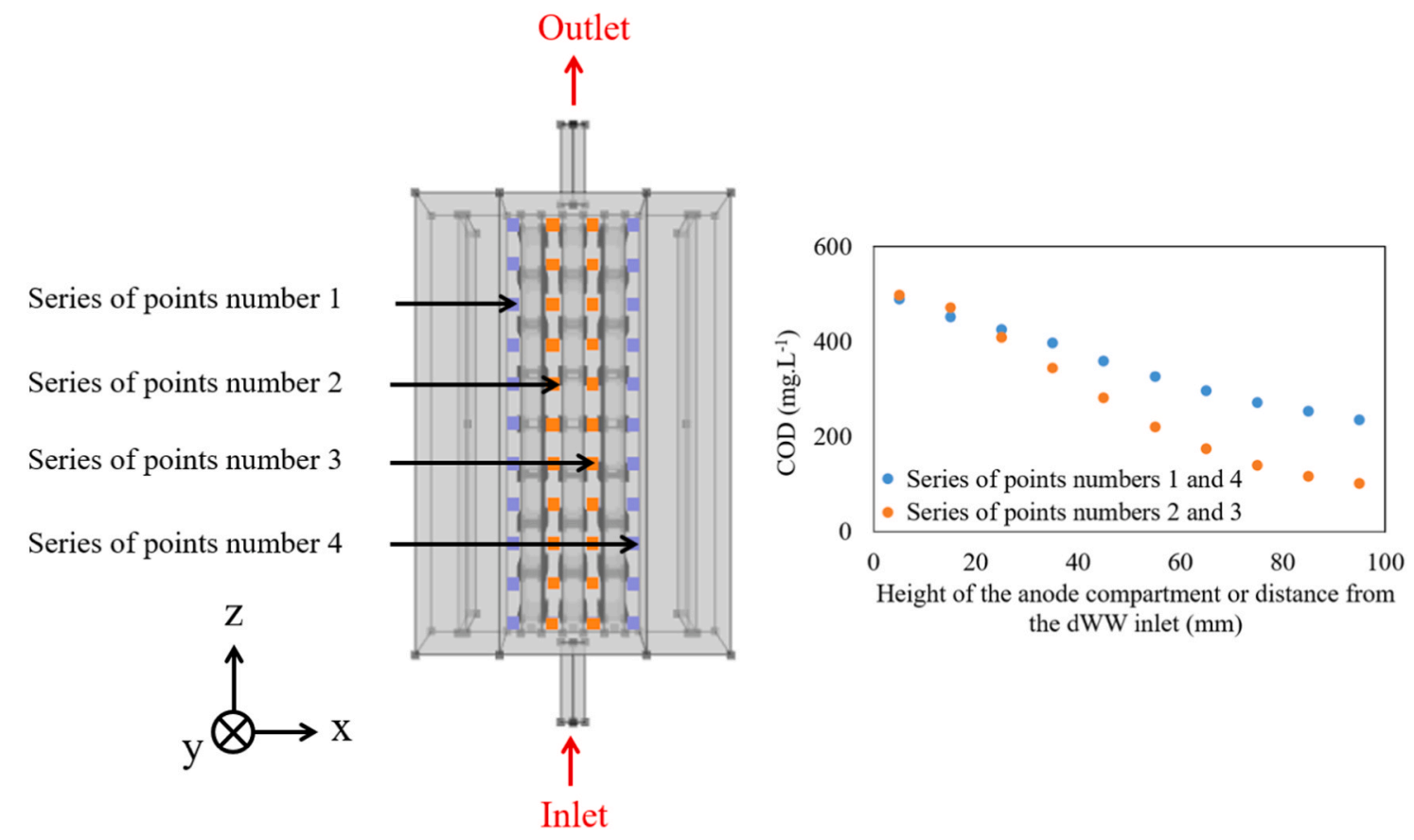

Fig. 9. Theoretical COD values for 4 series of points (Configuration F) for residence time of $8 \mathrm{~h}$, cell voltage of $1.0 \mathrm{~V}$, COD of $500 \mathrm{mg} \mathrm{L}^{-1}$ in the reactor inlet and bioanode thickness of $3 \times 5 \mathrm{~mm}$. 

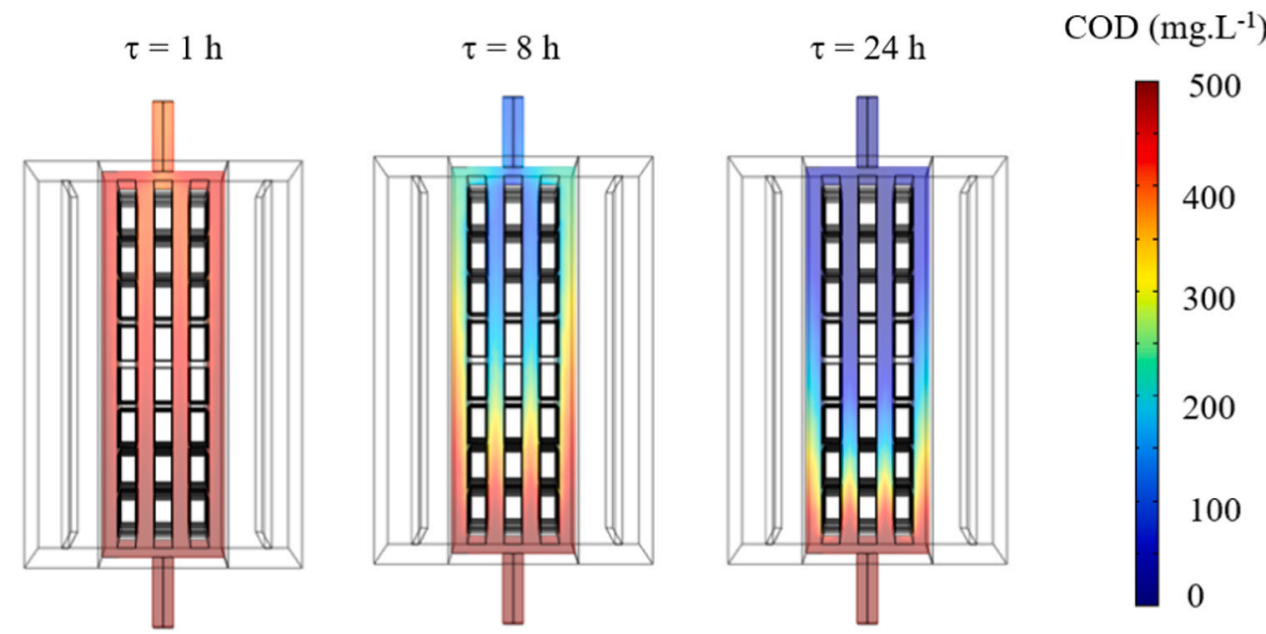

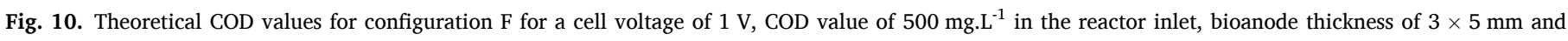
residence time values of $1 \mathrm{~h}, 8 \mathrm{~h}$ and $24 \mathrm{~h}$.

when the objective is to use numerical modelling to scale up MEC and other bioelectromicrobial technologies such as MFC to large size systems.

Another limitation of the actual model is that the COD consumed at the electrode-dWW interface only results from the oxidation of the soluble molecules of organic matter consumed by the electroactive biofilm. The experimental data used as input to the software are indeed voltammetry measurements and soluble COD determinations (filtered liquid samples). The reality is that a certain fraction of the organic matter in the dWW is either particulate and/or complex, i.e. less biodegradable. There is therefore a risk of overestimating the removal of COD with our modelling approach. In future research and model development, one of the points to improve the accuracy of the model will be to take into account the complexity of the composition of organic matter in dWW.

Experimental results that will be obtained in a lab-scale multi compartment pilot with 3D anodes (superimposed plates) will be compared with modelling results from this manuscript in Part II: Experimental results.

\section{CRediT authorship contribution statement}

Rémy Lacroix: Conceptualization, Methodology, Formal analysis, Investigation, Writing - original draft, Visualization, Writing - review \& editing. Emma Roubaud: Conceptualization, Formal analysis, Investigation, Writing - original draft, Writing - review \& editing. Benjamin Erable: Conceptualization, Resources, Writing - original draft, Writing review \& editing, Supervision, Project administration, Funding acquisition. Luc Etcheverry: Conceptualization, Resources, Writing - original draft, Writing - review \& editing, Supervision. Alain Bergel: Conceptualization, Writing - original draft, Writing - review \& editing, Supervision. Régine Basséguy: Conceptualization, Writing - original draft, Writing - review \& editing, Supervision. Serge Da Silva: Conceptualization, Resources, Writing - original draft, Writing - review \& editing, Supervision, Project administration, Funding acquisition.

\section{Declaration of Competing Interest}

The authors declare that they have no known competing financial interests or personal relationships that could have appeared to influence the work reported in this paper.

\section{Acknowledgments}

This work was funded by the Agence Nationale de la Recherche (France) within the framework of the WE-MET project (ERANETMED 2015 European call).

\section{Appendix A. Supporting information}

Supplementary data associated with this article can be found in the online version at doi:10.1016/j.jece.2021.105476.

\section{References}

[1] S.S. Lim, E.H. Yu, W.R.W. Daud, B.H. Kim, K. Scott, Bioanode as a limiting factor to biocathode performance in microbial electrolysis cells, Bioresour. Technol. 238 (2017) 313-324, https://doi.org/10.1016/j.biortech.2017.03.127.

[2] F. Zhao, E.S. Heidrich, T.P. Curtis, J. Dolfing, The effect of anode potential on current production from complex substrates in bioelectrochemical systems: a case study with glucose, Appl. Microbiol. Biotechnol. 104 (2020) 5133-5143, https:// doi.org/10.1007/s00253-020-10547-6.

[3] M. Zeppilli, H. Chouchane, L. Scardigno, M. Mahjoubi, M. Gacitua, R. Askri, A. Cherif, M. Majone, Bioelectrochemical vs hydrogenophilic approach for $\mathrm{CO}_{2}$ reduction into methane and acetate, Chem. Eng. J. 396 (2020), 125243, https:// doi.org/10.1016/j.cej.2020.125243.

[4] B. Logan, S. Cheng, V. Watson, G. Estadt, Graphite fiber brush anodes for increased power production in air-cathode microbial fuel cells, Environ. Sci. Technol. 41 (2007) 3341-3346, https://doi.org/10.1021/es062644y.

[5] R. Rousseau, X. Dominguez-Benetton, M.-L. Délia, A. Bergel, Microbial bioanodes with high salinity tolerance for microbial fuel cells and microbial electrolysis cells, Electrochem. Commun. 33 (2013) 1-4, https://doi.org/10.1016/j. elecom.2013.04.002.

[6] M. Zeppilli, M. Simoni, P. Paiano, M. Majone, Two-side cathode microbial electrolysis cell for nutrients recovery and biogas upgrading, Chem. Eng. J. 370 (2019) 466-476, https://doi.org/10.1016/j.cej.2019.03.119.

[7] J. You, R.J. Preen, L. Bull, J. Greenman, I. Ieropoulos, 3D printed components of microbial fuel cells: towards monolithic microbial fuel cell fabrication using additive layer manufacturing, Sustain. Energy Technol. Assess. 19 (2017) 94-101, https://doi.org/10.1016/j.seta.2016.11.006.

[8] F. Calignano, T. Tommasi, D. Manfredi, A. Chiolerio, Additive manufacturing of a microbial fuel cell—a detailed study, Sci. Rep. 5 (2015) 17373, https://doi.org/ $10.1038 /$ srep 17373.

[9] S.F. Ketep, A. Bergel, A. Calmet, B. Erable, Stainless steel foam increases the current produced by microbial bioanodes in bioelectrochemical systems, Energy Environ. Sci. 7 (2014) 1633-1637, https://doi.org/10.1039/C3EE44114H.

[10] S. Chen, Q. Liu, G. He, Y. Zhou, M. Hanif, X. Peng, S. Wang, H. Hou, Reticulated carbon foam derived from a sponge-like natural product as a high-performance anode in microbial fuel cells, J. Mater. Chem. 22 (2012) 18609, https://doi.org/ 10.1039/c2jm33733a.

[11] M.-F. Lai, C.-W. Lou, J.-H. Lin, Improve 3D electrode materials performance on electricity generation from livestock wastewater in microbial fuel cell, Int. J. Hydrog. Energy 43 (2018) 11520-11529, https://doi.org/10.1016/j. ijhydene.2017.06.047. 
[12] P. Chong, B. Erable, A. Bergel, Effect of pore size on the current produced by 3dimensional porous microbial anodes: a critical review, Bioresour. Technol. 289 (2019), 121641, https://doi.org/10.1016/j.biortech.2019.121641.

[13] D.A. Jadhav, A.A. Carmona-Martínez, A.D. Chendake, S. Pandit, D. Pant, Modeling and optimization strategies towards performance enhancement of microbial fuel cells, Bioresour. Technol. 320 (2021), 124256, https://doi.org/10.1016/j. biortech.2020.124256.

[14] S. Gadkari, S. Gu, J. Sadhukhan, Two-dimensional mathematical model of an aircathode microbial fuel cell with graphite fiber brush anode, J. Power Sour. 441 (2019), 227145, https://doi.org/10.1016/j.jpowsour.2019.227145.

[15] S. Gadkari, J.-M. Fontmorin, E. Yu, J. Sadhukhan, Influence of temperature and other system parameters on microbial fuel cell performance: numerical and experimental investigation, Chem. Eng. J. 388 (2020), 124176, https://doi.org/ 10.1016/j.cej.2020.124176.

[16] K.M. Hernández-García, B. Cercado, F.A. Rodríguez, F.F. Rivera, E.P. Rivero, Modeling 3D current and potential distribution in a microbial electrolysis cell with augmented anode surface and non-ideal flow pattern, Biochem. Eng. J. 162 (2020), 107714, https://doi.org/10.1016/j.bej.2020.107714.

[17] Y. Reyes-Vidal, J. López-Maldonado, F. Castañeda, G. Orozco, F.F. Rivera, Evaluation of inlet design and flow rate effect on current density distribution in a microbial electrolysis cell using computational simulation techniques, coupling hydrodynamics and bioanode kinetics, Int. J. Chem. React. Eng. (2018) 16, https:// doi.org/10.1515/ijcre-2017-0259.

[18] M. Oliot, L. Etcheverry, R. Mosdale, A. Bergel, Microbial fuel cells connected in series in a common electrolyte underperform: understanding why and in what context such a set-up can be applied, Electrochim. Acta 246 (2017) 879-889, https://doi.org/10.1016/j.electacta.2017.06.114.

[19] E. Roubaud, R. Lacroix, S. Da Silva, A. Bergel, R. Basséguy, B. Erable, Catalysis of the hydrogen evolution reaction by hydrogen carbonate to decrease the voltage of microbial electrolysis cell fed with domestic wastewater, Electrochim. Acta 275 (2018) 32-39, https://doi.org/10.1016/j.electacta.2018.04.135.

[20] R. Rousseau, L. Etcheverry, E. Roubaud, R. Basséguy, M.-L. Délia, A. Bergel, Microbial electrolysis cell (MEC): strengths, weaknesses and research needs from electrochemical engineering standpoint, Appl. Energy 257 (2020), 113938, https://doi.org/10.1016/j.apenergy.2019.113938.

[21] J.A. Baeza, À. Martínez-Miró, J. Guerrero, Y. Ruiz, A. Guisasola, Bioelectrochemical hydrogen production from urban wastewater on a pilot scale, J. Power Sour. 356 (2017) 500-509, https://doi.org/10.1016/j. jpowsour.2017.02.087.

[22] L. Gil-Carrera, A. Escapa, R. Moreno, A. Morán, Reduced energy consumption during low strength domestic wastewater treatment in a semi-pilot tubular microbial electrolysis cell, J. Environ. Manag. 122 (2013) 1-7, https://doi.org/ 10.1016/j.jenvman.2013.03.001.

[23] L. Gil-Carrera, A. Escapa, B. Carracedo, A. Morán, X. Gómez, Performance of a semi-pilot tubular microbial electrolysis cell (MEC) under several hydraulic retention times and applied voltages, Bioresour. Technol. 146 (2013) 63-69, https://doi.org/10.1016/j.biortech.2013.07.020.

[24] M.I. San-Martín, A. Sotres, R.M. Alonso, J. Díaz-Marcos, A. Morán, A. Escapa, Assessing anodic microbial populations and membrane ageing in a pilot microbia electrolysis cell, Int. J. Hydrog. Energy 44 (2019) 17304-17315, https://doi.org/ 10.1016/j.ijhydene.2019.01.287.

[25] S. Da Silva, R. Basséguy, A. Bergel, Electrochemical deprotonation of phosphate on stainless steel, Electrochim. Acta 49 (2004) 4553-4561, https://doi.org/10.1016/j electacta.2004.04.039.

[26] L. De Silva Muñoz, A. Bergel, D. Féron, R. Basséguy, Hydrogen production by electrolysis of a phosphate solution on a stainless steel cathode, Int. J. Hydrog. Energy 35 (2010) 8561-8568, https://doi.org/10.1016/j.ijhydene.2010.05.101.

[27] L. De Silva Muñoz, A. Bergel, R. Basséguy, Role of the reversible electrochemical deprotonation of phosphate species in anaerobic biocorrosion of steels, Corros. Sci. 49 (2007) 3988-4004, https://doi.org/10.1016/j.corsci.2007.04.003.

[28] A. Tugirumubano, H. Jae Shin, L.K. Kwac, H.G. Kim, Numerical simulation of the polymer electrolyte membrane electrolyzer, IOSR 13 (2016) 94-97, https://doi. org/10.9790/1684-1305069497.

[29] M.F. Kaya, N. Demir, Numerical investigation of PEM water electrolysis performance for different oxygen evolution electrocatalysts, Fuel Cells 17 (2017) 37-47, https://doi.org/10.1002/fuce.201600216.

[30] X. Jin, X. Xue, Computational fluid dynamics analysis of solid oxide electrolysis cells with delaminations, Int. J. Hydrog. Energy 35 (2010) 7321-7328, https://doi. org/10.1016/j.ijhydene.2010.04.158.

[31] X. Jin, X. Xue, Mathematical modelling analysis of regenerative solid oxide fuel cells in switching mode conditions, J. Power Sour. 195 (2010) 6652-6658, https:/ doi.org/10.1016/j.jpowsour.2010.04.018.
[32] L. Cai, R.E. White, Mathematical modelling of a lithium ion battery with thermal effects in COMSOL Inc. Multiphysics (MP) software, J. Power Sour. 196 (2011) 5985-5989, https://doi.org/10.1016/j.jpowsour.2011.03.017.

[33] V. Ramadesigan, P.W.C. Northrop, S. De, S. Santhanagopalan, R.D. Braatz, V. R. Subramanian, Modelling and simulation of lithium-ion batteries from a systems engineering perspective, J. Electrochem. Soc. 159 (2012) R31-R45, https://doi. org/10.1149/2.018203jes.

[34] R. Lacroix, J.J. Biendicho, G. Mulder, L. Sanz, C. Flox, J.R. Morante, S. Da Silva, Modelling the rheology and electrochemical performance of $\mathrm{Li}_{4} \mathrm{Ti}_{5} \mathrm{O}_{12}$ and $\mathrm{LiNi}_{1}$ ${ }_{3} \mathrm{Co}_{1 / 3} \mathrm{Mn}_{1 / 3} \mathrm{O}_{2}$ based suspensions for semi-solid flow batteries, Electrochim. Acta 304 (2019) 146-157, https://doi.org/10.1016/j.electacta.2019.02.107.

[35] R. Lacroix, S.D. Silva, M.V. Gaig, R. Rousseau, M.-L. Délia, A. Bergel, Modelling potential/current distribution in microbial electrochemical systems shows how the optimal bioanode architecture depends on electrolyte conductivity, Phys. Chem. Chem. Phys. 16 (2014) 22892-22902, https://doi.org/10.1039/C4CP02177K.

[36] A.A. Carmona-Martínez, R. Lacroix, E. Trably, S. Da Silva, N. Bernet, On the actual anode area that contributes to the current density produced by electroactive biofilms, Electrochim. Acta 259 (2018) 395-401, https://doi.org/10.1016/j electacta.2017.10.200.

[37] K.M. Hernández-García, B. Cercado, F.A. Rodríguez, F.F. Rivera, E.P. Rivero, Modelling 3D current and potential distribution in a microbial electrolysis cell with augmented anode surface and non-ideal flow pattern, Biochem. Eng. J. 162 (2020), 107714, https://doi.org/10.1016/j.bej.2020.107714.

[38] K.M. Hernández-García, B. Cercado, E.P. Rivero, F.F. Rivera, Theoretical and experimental evaluation of the potential-current distribution and the recirculation flow rate effect in the performance of a porous electrode microbial electrolysis cell (MEC), Fuel 279 (2020), 118463, https://doi.org/10.1016/j.fuel.2020.118463.

[39] A.M. Sahar, J. Wissink, M.M. Mahmoud, T.G. Karayiannis, M.S. Ashrul Ishak, Effect of hydraulic diameter and aspect ratio on single phase flow and heat transfer in a rectangular microchannel, Appl. Therm. Eng. 115 (2017) 793-814, https://doi. org/10.1016/j.applthermaleng.2017.01.018.

[40] Stainless Steel 316L, 〈https://www.lenntech.com/stainless-steel-316l.htm $\rangle$, retrieved online (October 2018).

[41] M. Rimboud, D. Pocaznoi, B. Erable, A. Bergel, Electroanalysis of microbial anodes for bioelectrochemical systems: basics, progress and perspectives, Phys. Chem. Chem. Phys. 16 (2014) 16349-16366, https://doi.org/10.1039/C4CP01698J.

[42] M. Oliot, P. Chong, B. Erable, A. Bergel, Influence of the electrode size on microbial anode performance, Chem. Eng. J. 327 (2017) 218-227, https://doi.org/10.1016/ j.cej.2017.06.044.

[43] E. Roubaud, R. Lacroix, S. Da Silva, L. Etcheverry, A. Bergel, R. Basséguy, B. Erable, Benchmarking of Industrial synthetic graphite grades, carbon felt, and carbon cloth as cost-efficient bioanode materials for domestic wastewater fed microbial electrolysis cells, Front. Energy Res. 7 (2019) 106, https://doi.org/10.3389/ fenro. 2019.00106.

[44] E.L. Clusser. Diffusion Mass Transfer in Fluid Systems, Second ed., Cambridge University Press, 1997.

[45] D. Pant, G. Van Bogaert, L. Diels, K. Vanbroekhoven, A review of the substrates used in microbial fuel cells (MFCs) for sustainable energy production, Bioresour. Technol. 101 (2010) 1533-1543, https://doi.org/10.1016/j.biortech.2009.10.017.

[46] E.E. Hills, M.H. Abraham, A. Hersey, C.D. Bevan, Diffusion coefficients in ethanol and in water at $298 \mathrm{~K}$ : linear free energy relationships, Fluid Phase Equilib. 303 (2011) 45-55, https://doi.org/10.1016/j.fluid.2011.01.002.

[47] X. Zhu, M.D. Yates, M.C. Hatzell, H. Ananda Rao, P.E. Saikaly, B.E. Logan, Microbial community composition is unaffected by anode potential, Environ. Sci. Technol. 48 (2014) 1352-1358, https://doi.org/10.1021/es404690q.

[48] B. Cercado, N. Byrne, M. Bertrand, D. Pocaznoi, M. Rimboud, W. Achouak, A. Bergel, Garden compost inoculum leads to microbial bioanodes with potentialindependent characteristics, Bioresour. Technol. 134 (2013) 276-284, https://doi. org/10.1\%20016/j.biortech.2013.01.123.

[49] R. Rousseau, M. Rimboud, M.-L. Délia, A. Bergel, R. Basséguy, Electrochemical characterization of microbial bioanodes formed on a collector/electrode system in a highly saline electrolyte, Bioelectrochemistry 106 (2015) 97-104, https://doi. org/10.1016/j.bioelechem.2015.06.011.

[50] S. Gadkari, J.-M. Fontmorin, E. Yu, J. Sadhukhan, Influence of temperature and other system parameters on microbial fuel cell performance: Numerical and experimental investigation, Chem. Eng. J. 388 (2020), 124176, https://doi.org/ 10.1016/j.cej.2020.124176.

[51] H. Guo, Y. Kim, Stacked multi-electrode design of microbial electrolysis cells for rapid and low-sludge treatment of municipal wastewater, Biotechnol. Biofuels 12 (2019) 23, https://doi.org/10.1186/s13068-019-1368-0.

[52] H. Moon, I.S. Chang, J.K. Jang, B.H. Kim, Residence time distribution in microbial fuel cell and its influence on COD removal with electricity generation, Biochem. Eng. J. 27 (2005) 59-65, https://doi.org/10.1016/j.bej.2005.02.010. 